\title{
STRATEGIES IN LEARNING SPEAKING SKILLS USED BY THE ADULT EFL STUDENTS
}

\author{
Pratiwi Samad $^{1}$ \\ Universitas Pohuwato \\ Pratiwisamad@unipo.ac.id \\ Wira Kafryawan ${ }^{2}$ \\ Institut Agama Islam Negeri Fattahul Muluk Papua \\ wira@iainfmpapua.ac.id
}

\begin{abstract}
This research was conducted to find out and to describe the speaking skills strategies used by the adult EFL students of Pohuwato University and the adults' reason for using those strategies in learning speaking skills. The qualitative descriptive has been employed as the method of the research, and the researcher took the students in the fourth semester of the English department of Pohuwato University as the subject of the research through purposive sampling. To obtain the data, the researcher used the interview and observation as the instrument. The result of the data shows that there are three strategies used by adult EFL students in learning speaking skills. They are cognitive, metacognitive, and socio-affective strategies. In cognitive strategy, the students mostly like to apply practicing and analyzing and reasoning. In metacognitive, they used to apply arranging and planning and monitoring, and in socio-affective, they applied to cooperate with others as their strategies to use in learning speaking skills.
\end{abstract}

Keywords: Speaking Strategies, Adult, EFL Students.

\section{INTRODUCTION}

An adaptive and open-minded teacher will help the students build up their spirit and motivation with their different learning styles. They support their students in order to better prepare for learning, especially in spoken language. In achieving the language, the students experience two different aspects of learning. They are called the language of the implicit and explicit process of language process. A learner gets their childhood language in the implicit process without experiencing too much- complicated thinking to process their spoken. It was happening naturally and in an unconscious situation. While the explicit could be more concerned because of the monitoring process of achieving the language. For that explanation of Ellis et al (2018:14) describes that these two theories of achieving language might happen in different ages and situations of learning.

Concerning this as the point of view to create better teaching and students' achievement, all the component of teaching should be more improved to prepare the teachers' and learners' strategy of teaching and learning speaking skills. Many teachers for current time arrange and develop a strategy as many as needed by the learners although sometimes they teach the language despite concerning the different strategist used to experience many various components, especially in spoken language and the way they deprive the learners' anxiety in the classroom that most of them are confusing in arranging their strategy for facing their subject. For students' better progress of learning, the teachers are expected to fulfill their skills in better performance as their ways to take the successful learning either inside or outside the classroom. Triq et al (2020:3-4) to create good and successful learning, a teacher should get used to becoming a good learner in order to 
create the behaviour and good process of thought although It is not easy to place teacher's situation to be a good model for their students.

The teachers, however, should prepare their selves to be ready in supporting their students in order that they could gain and help the students acquire the language. When the students express their ideas in a good manner and manage their strategies, they could help them solve their feelings when trying to speak in English. To find the better ways of students' success in learning and using strategies, the researcher proposes to do the research at Pohuwato University in observing the use of the strategies of speaking skills used by the adults and getting the reason of the adults' students using the strategies as their ways in learning speaking skills.

The first idea is learning strategy. Based on what Hong Shi (2017:24) stated about Learning strategies, it is stated that there are some steps taken by learners to enhance their learning in managing their lessons' process. This is done in order to help the learners develop their skills and confidence to motivate them to follow their subject. Besides, O'Malley and Chamot (1990:1) defined that there are special thoughts and behaviour used by the individual or the learners to help them understand and preserve new information of the language. These ideas are prepared to learn something new then becomes good management for the learners. According to Scarcella \& Oxford in Taheri et al. (2019:21), Learning strategies are defined as "specific behaviours, thoughts actions, steps, or techniques-such as seeking out conversation partners, or giving oneself encouragement to tackle a difficult language task-used by students to enhance their own learning explained by. This effort of learning enhances the learners' ability in the English learning process. They believe that the utilize of learning strategies could help the learners to communicate clearly to their partner of speaking skills.

Learning strategies entail the management of learning English as a second language. Wenden in Wael et al. (2018:66) not only underlines the learning strategy as the management of learners' preparation to seek the information but also, they have to pay attention and concern about what strategy they use. Learning strategy, however, was identified to create a suitable technique for the learners without obviating the language approach itself. In supporting the data, Platt in Zare (2012:2) also stated that that an easy way of organizing the learners thinking by managing a good strategy for better understanding of their subject.

The above concepts of learning strategy, the researcher concludes that the learning strategy is a process of managing the teaching plan, which prepares the learning methods and techniques to be analyzed and learned further in order to develop the learner's skills and comprehension. To obtain the best result from the process of spoken language, the learners must better prepare for the steps and pay attention to their behaviour and thoughts in achieving a piece of new information from the language. The second idea is about classification of language learning strategies. It was proposed by some researchers and experts of language learning taxonomy for the concept of learning strategy. They applied some in different cases of the learners at their schools and universities. Most learners tried their better achievement by managing their strategies.

Those strategies are categorized into three parts of taxonomy. They are cognitive, metacognitive, and socio-affective strategies. It has been proposed that O'Malley in Razmjoo (2011:118) propose the above there different of taxonomy in language strategies of learning. By considering those aspects of different strategies learning without concerning the other strategies that might come over by the students when trying to determine what strategies they should apply to influence their speaking skills and 
achievement. It is found that the concepts of the metacognitive included in the learners' ways in arranging and thinking about the learning.

The purpose of applying them is to help learners in planning for learning and thinking about the process of the learning process. In order to control their progress, monitoring production and comprehension, as well as evaluation, are done after the completion of spoken language. Besides, Oxford (2003:12) explanation also mentioned in her paper about metacognitive strategy is that identifying one's own learning style preferences and needs, planning for L2 task, gathering and organizing materials, arranging a study space and a schedule, monitoring mistakes, and evaluating task success, and evaluating the success of any type of learning strategy).

Affective strategies are such as identifying one's mood and anxiety level, talking about feelings, rewarding oneself for good performance, and using deep breathing or positive self-talk. As mentioned by Drayer and Oxford in Oxford (2003:14) stated that among South African EFL learners and by Oxford and Ehrman in Oxford (2013:14) among native English speakers learning a foreign language used the affective as the way to get the higher proficiency of learning. This strategy helps the learners learn through interaction with others because the impact of this is lowering the students' anxiety, encouraging their self and solve the emotional temperature. The explanation was also supported by Oxford in Wahyuni (2013:47).

Social strategies (e.g., asking questions to get verification, asking for clarification of a confusing point, asking for help in doing a language task, talking with a nativespeaking conversation partner, and exploring cultural and social norms) help the learner work with others and understand the target culture as well as the language. Social train the students to build up their communication process in their learning process.

To achieve better comprehension, Doryei in Tsai (2018:4) mentioned two strategies used in learning speaking skills. They are two ways and tips to help learners for better communication. The first is avoiding the linguistic pattern component of English so that students could be well providing a good idea without any monitoring process, and the second is by applying the compensation strategy. This strategy concentrates on message abandon, code-switching, word coinage, topic avoidance and the use of time strategy. The cognitive, metacognitive and socio-affective strategy becomes the strategies concept that is used to group the strategies so that the researcher will not get difficult in grouping the adult learners when trying to analyze and determine what strategies they use. This strategy then classified based on its sub- strategies to reveals further information from the adult EFL students of Pohuwato University.

The third idea is the importance of language learning strategy. The learning strategy is very useful for the learners. There are some explanations to this writer's statement based on the language theories. A good learner could be seen from his/her strategy in arranging their plans and achieving his/her goal. Chamot (1998:3), The intent of learning strategies instruction is to help all students become better language learners. When students begin to understand their own learning processes and can exert some control over these processes, they tend to take more responsibility for their own learning. This selfknowledge and skill in regulating one's own learning is a characteristic of good learners, including good language learners. Research with both first and second language learners is revealing some of the ways of thinking that guide and assist an individual's attempts to learn more effectively. He also stated that Good language learners are more strategic than less effective language learners. By "strategic," I mean that they are better able to figure 
out the task requirements and are flexible in their approach to solving any problems they encounter while working on the task.

Unsuccessful language learners, on the other hand, while not necessarily unaware of strategies, have difficulty in choosing the best strategy for a specific task and often have a limited variety of strategies in their repertoire. Based on Paris's explanation in Chamot (1990:5), Students who are more strategic learners are more motivated to learn and have a higher sense of self- efficacy, or confidence in their own learning ability. Language Learning Strategies (LLS) are important because the student use to help them become better language learners and better in communication competence as Oxford in Dolati (2014:39) clarifies, LLS "... is especially important for language learning because they are tools for active, self-directed involvement, which is essential for developing communicative competence".

Dolati \& Mousavi (2014:39) The term LLS is used more generally for all strategies that L2/FL learners use in learning the target language. LLS can help learners learn effectively, and effective learning motivates students so that they become autonomous learners. If students can understand the importance of language learning strategies and equipped themselves with these strategies as techniques, learner autonomy will be fostered, and the difficulties encountered while learning the language will be mitigated. As one outcome, promoting learning autonomy may boost a learner's desire for learning. A study by O'Malley \& Chamot in Dolati \& Mousavi (2014:39) also suggests that effective L2/FL learners are aware of the LLS they use and why they use them. Then for a clearer explanation.

The fourth idea is speaking skills. Communication is used to express people's ideas in doing their interaction orally. In speaking or communicate with other people, they use their ideas to express their feelings and thought from their spoken language they used. Many learners had determined their success with pay attention to the progress of their skill in spoken language. Richards (2008:19) reveals that the learners can realize how far they have convinced themselves of fluency in speaking.

In this way, Parlindungan (2020:42) also describes that speaking skills are an expression of opinions, ideas, and feelings in order to build up human relations in society. People use it as their way of knowing one another. In other words, Oxford in Azmi also stated that (2012:126) words are spelled from speaking skills interaction. People say the words and utterances through their brains and arbitrary organs. To this end, the researcher could say that speaking skills are the component of skill that expresses through the words then used to create an interaction so that students could express their ideas and feelings. To communicate clearly to other people, students need to use speaking skills and enhance their vocabularies to achieve a good improvement in mastering the spoken language. Students as foreign students should pay attention to this skill that becomes more known as the first subject to determine someone's English progress. The fifth idea is about age differentiation in experiencing the language. In acquiring and achieving the language, some factors have to be considered by the teachers and the learners. Different ways and strategies are used to express the learner's ideas in saying something in words and sentences. So that, it is very considered that students need to prepare their strategy learning from both children and adults.

Krashen in Devanagari (2015:6) explained that children in the unconscious condition are better at acquiring language. The children, however, will be difficult after getting five years, which differs from the adults that more difficult to achieve the language. A set of the linguistic process had fulfilled their mind to control their thought 
of spoken language. Margaret (2015:6) also proposed that children are better at understanding the language. A simple thought and feeling do not disturb them to comprehend the language. It more helps the child learners when the language is met with the audio and visual media as their tools to get easier experience the language. The adult maturity limited them to easier access to experiencing the new language. A complex though had many rules of controlled ideas which are not managed well when they do not prepare their subject.

Therefore, the adults and children could be measured differently by comprehending the above explanation. Children with their simple vocabularies can understand and express their feeling without too much worried while the adults have been monitored by the linguistic factor and complex then create the complex though. Through this fact, the adults will get complicated to make communication clear to their partners. From this theory, the researcher concludes that there are many differences in learning by acquiring or achieving the language by children and adults because people of different ages have different needs, competencies, and cognitive skills. The last is about adult learners.

Valipour \& Asl (2014:1) reveals that because of great attention to grammatical rules, adult learners could support themselves in creating good sentences. Maturity helps them manage their learning and achieve their goals to better English and life goal. She also stated that adults' consideration for structure and monitoring would get them to succeed in learning. A complex mind and monitoring their language are known better becomes the adult's problem. The monitor users control the adult's progress of learning and help them solve their mistakes and problems. Therefore, good management should be considered for the adult's ways and strategies through the learning process. This age mostly in the worrying condition in concerning many things happens around them. The definition above then concluded by the researcher that the adults are the ages of an individual between 20 to 40 years old. The subject of adults that taken in this research is the adults whose ages in 20 years above and the adult learners as the object who study in Pohuwato University of Gorontalo.

\section{METHODS}

This research was done by conducting the qualitative descriptive method that concerning the purpose of finding further information about the adult EFL students' ways of strategies in speaking skills and their reason to use them as their strategies. The qualitative method will describe the research as qualitatively the description results of the research, and the descriptive research is used to explain the further phenomenon and its characters and specification of the process of learning from the student's activity. Nasaji in Sari (2020:22) also stated that the research is more paying attention to how or why something had happened from the progress and process of the research activity observe.

The two variables are taken from this research, they are: a) the dependent variable is the strategies in learning speaking skills as the strategy used by the students at the University of Pohuwato. The strategies are included in the cognitive, metacognitive and socio- affective strategies. b) the Independent variable is the adult learners. The adult's age is above 18 years old. They are the fourth-semester students at the Pohuwato University of Gorontalo. The population of this research is the students of Pohuwato University of Gorontalo. They are from the fourth semester that consists of one class of English Department of Pohuwato University. Those students consist of 24 students. 
The sample techniques were taken by choosing the purposive sampling. Purposive sampling is the technique of sample which was used in this research by considering the participants' skill of speaking skills for every student at the Pohuwato University of Gorontalo. There are two instruments that have been used in this study, namely semistructured interview and observational checklist.

The semi-structured interview was the first instrument applied in this research. According to Marriam's explanation in Hsu (2019: 153), semi- structured interviews become the source to create the topics and questions are handled through the interview's expediency. The interview was done in collecting the data of adult EFL students of Pohuwato University in using their strategies in speaking skills. A placed to get the clear data was chosen to prevent the noisy situation so that the researcher prefers to do the interview in a silent room and pay attention to the learners' distance. The second instrument was observational checklist. This was conducted to describe briefly the students learning activity when applying the research. The description was taken from the blended learning process at their class, offline and virtual. This activity helps the researcher determine students' strategies applying and from their activity that reveals many different expressions in following their class. The observational checklist was done in the fourth semester of students at the Pohuwato University of Gorontalo. This was done by checking and observing the students' activity when the learning process run. In this way, the researcher gave the same questions with interrupting or asking more for getting a clear explanation.

\section{FINDINGS AND DISCUSSION}

As the main goal of the research's purpose, the researcher needs to find more about the strategies in learning speaking skills used by the adult EFL students of Pohuwato University. This has been analyzed and categorized in three different strategies that have been determined from the interview and observational result. The researcher has concluded to answer the problem research by the following explanation:

Learning strategy on speaking skills of adults is the first to focus. It is found that cognitive strategy becomes mostly used and applied by the adults as their strategy to express their ideas and feelings. The second strategy applied by the adults was in metacognitive strategy. This is done as the strategy of the adult EFL students in helping them arranging and thinking about their progress of learning as has been said by As O'Malley in Razmjoo (2011:118). The description was taken to help learners managing their plan oh how they are planning their progress, monitoring their achievement and comprehension, as well as evaluation after the completion of an activity. The explanation also supported by Oxford (2003:12), which also mentioned in her result of a study that metacognitive strategy is knowing someone's style of learning through their plan based on what they need, to avoid a mistake, they must prepare good arranging and organizing subject, prepare their schedule as their support to help them monitor their mistakes and solve them by evaluating their progress of learning.

Besides, the adults used socio- affective strategy as their last strategy in order to support them in encouraging themselves and the ways of taking their emotional temperature as Oxford (1990:475) mentioned the explanation of social and affective strategy. Social strategies for learning with others and affective strategy for regulating emotions while learning). The socio-affective strategy mostly used was in the substrategy of encouraging students' self, monitoring and arranging and planning. 
Why do adult learners use the learning strategies in speaking skills class? In a qualitative process in obtaining the data, there are many answers of explanation that reveals the learner's reasons for having applied the strategies when following their activity and answering the researcher answers from the interview session. Strategies, in this case, had helped the learners more in comprehending their subject, especially in learning speaking skills. This contribution not only useful in the process of understanding the adult EFL students' subject but also help them arrange and organize their plan and progress of learning and easier responding the subject ad interaction of their speaking skills. The one and very important reason are to help learners concentrate on their life and future progress in learning and earning. The result of the research shows that most adult EFL students of Pohuwato University get used to applying the strategies for their better goals and planning management for easier in understanding speaking skills and better responding of speaking skills discuss and ideas organization. Valipour \& Asl (2014:1) had concluded that better preparation in realizing their monitoring the linguistic components will help them more understand the grammar and create better writing as their concept to explore their thoughts and as their preparation to fix their language process.

The result shows that the adult EFL students used to apply the cognitive strategy that consists of practicing, analyzing, and reasoning strategies to help them comprehend their learning in speaking skills subject. In practice, the students, by using memory ad taking notes, could help them create their ideas to be spoken. Analyzing and reasoning support them in pay attention to the grammar rules and monitoring their mistakes so that they are careful in making mistakes then prepare their best for better achievement.

The cognitive categorized are mostly used by adult EFL students to help them memorize, practice, taking notes and analyzing and reasoning their process of learning. The second strategy that was applied by the adult EFL students of Pohuwato University was a metacognitive strategy. This is done as the students' ways of better in practicing their spoken language. The last strategy used was a socio-affective strategy, which is very needed for the students' positive vibes and statements, and also students can briefly explain how they feel of something come over from their learning process.

\section{CONCLUSION}

Learning strategies used by the adult learners of the fourth semester at Pohuwato University are cognitive, metacognitive and socio-affective strategies. The most frequently used strategy was in cognitive, which its sub- strategies used are practicing and analysing and reasoning. The second strategy used to be applied metacognitive strategy that consists of arranging and planning, monitoring and cantering students' learning. A socio-affective strategy which its sub-strategies included cooperating with others, taking students' emotional temperature and encouraging students' self. b) there are some benefits of applying the strategies that are veryneeded by the students. Besides the strategy help the adult EFL students prepare their topic of speaking skills, they can also comprehend the whole explanation and discussion topic of their subject and as their management strategyfor achieving their goals of English and their goal life.

\section{REFERENCES}

Al Azmi, H. (2012). The Students'Language Learning Strategies in Reading and Speaking. Al-Ta Lim Journal, 19(2), 122-133. 
Ali Fuziana et al. 2013. Memory and Cognitive Strategies of High Ability Students in a Rural Secondary School. University of Malaysia. Vol.6

Asl, H., \& Valipour, V. (2014). Teaching english as a foreign language to persian children vs. adults. Indian J. Fundam. Appl. Life, 5(S1),P.1

Anna uhl, Chamot. 1998. Teaching Learning Strategies to Language Students. Washington DC.

Bashir, Marriam. 2011. Factor Effecting Students' English Speaking Skills. University of Education. Bank Road Campus, Lahore.

Chang, Chih-hui. 2014. Language Learning Strategy Profile of University Foreign Language Majors in Taiwan. Vol.8

Ellis, R., \& Roever, C. (2018). The measurement of implicit and explicit knowledge. The Language Learning Journal, p.14

Ertner et al, 2013. Behaviorism, Cognitivism, Constructivism : Comparing Critical Features From an Instructional Design Perspective .Performance Improvement Quarterly. Wiley Online Library.

Gilakjani, Abbas Pourhosein. 2012. A Study of Factors Affecting EFL Learners' English PronunciationLearning and the Strategies for Instruction, Islamic Azad University.Iran. Vol.2

Gursoy, Esim. 2011. Krashen's Five Proposals on Language Learning: Are They Valid in Libyan EFL

Hendriani, Suswati. 2013. Developing aModel of Learning Strategy of Speaking skills English at Collage.English Department of State College for Islamic Studies. (Sekolah Tinggi Agama Islam Negeri), Batusangkar. West Sumatra. Indonesia. Vol.6

Hong-Nam, K., \& Leavel, A. G. (2006). Language learning strategy use of ESL students in an intensive English learning context. System, 34(3), 399-415

Krashen, Stephen. D. 1982. Principles and Practice In Second Language Acquisition. University of Southern California: Pergamon Press Inc.

Muelasa, A., \& Navarroa, E. (2015). Learning strategies and academic achievement. Procedia - Social and Behavioral Sciences, 165, 217-221

Nisbet, J., \& Shucksmith, J. (2017). Learning strategies. Routledge.

O’Malley, Michael J and Chamot, Anna Uhl. 1990. Strategies in Second Language Acquisition.Chambridge: Press Syndicate of the University of Chambridge.

O'Neil, H. F. (Ed.). (2014). Learning strategies. Academic Press.

Oxford, R. L. (1990). Language learning strategies: What every teacher should know. Boston, MA: Heinle and Heinle 
Oxford, R. L. (2014). What we can learn about strategies, language learning, and life from two extreme cases: The role of well-being theory. Studies in Second Language Learning and Teaching, 4(4), 237-274

Parlindungan, P. (2020). Improving the Students' Speaking Skills By Using Classroom Debate. Jurnal Estupro, 5(2),p.42

Razmjoo, S. A., \& GHASEMI, A. S. (2011). A model of speaking strategies for EFL learners.

Shi, H. (2017). Learning strategies and classification in education. Institute for Learning Styles Journal, 1(1), 24-36.

Taheri, H., Sadighi, F., Bagheri, M. S., \& Bavali, M. (2019). EFL learners' L2 achievement and its relationship with cognitive intelligence, emotional intelligence, learning styles, and language learning strategies. Cogent Education, 6(1),p.21

Tariq, Muhammad, et al. Using the cognitive apprenticeship model to identify learning strategies that learners view as effective in ward rounds. Postgraduate Medical Journal, 2020,p.: 3-4.

Uslu, M. E., Sahin, E., \& Odemis, I. S. (2016). The effect of language learning strategies on academic achievement. Journal of Educational and Instructional Studies in the World, 6(3), 73-78

Zafari, M., \& Biria, R. (2014). The Relationship between emotional intelligence and language learning strategy Use. Procedia - Social and Behavioral Sciences, 98, 1966-1974 